\title{
Perlindungan Hukum bagi Konsumen terhadap Keterlambatan Penerbangan Akibat Kabut Asap Kebakaran
}

\author{
Vermonita Dwi Caturjayanti \\ vermonitaa@gmail.com \\ Universitas Airlangga
}

\begin{abstract}
Keywords: $\quad$ Abstract
Delays; Flight;

Compensation;

Aviation services have become one of the primary needs for community mobilization.

Force Majeure.

In its implementation, until now there are still some obstacles, one of which is the flight delay. Delays in flights often occur due to weather and / or technical operational factors. If there is a flight delay, the airline is responsible for providing compensation to the passengers unless the airline can prove that the flight delay is caused by weather and / or operational technical factors. In-flight delays caused by haze can not be called a force majeure because it can be predicted by the airlines and can be said to be sustainable weather. On this basis, the airline is the party responsible for providing compensation to passengers. The relationship between the airline and the passenger is also bound by the transportation agreement. So the form of compensation for flight delays must be following the provisions contained in the legislation as a form of responsibility for the transportation agreement that is not following the agreement.
\end{abstract}

Kata Kunci:

Keterlambatan; Penerbangan; Ganti Rugi; Force Majeure.

\begin{abstract}
Abstrak
Jasa penerbangan telah menjadi salah satu kebutuhan primer untuk mobilisasi masyarakat. Dalam pelaksanaannya hingga saat ini masih terjadi beberapa kendala, salah satunya adalah keterlambatan penerbangan. Keterlambatan dalam penerbangan sering terjadi dikarenakan faktor cuaca dan/atau teknis operasional. Setiap terjadi keterlambatan penerbangan maka pihak maskapai penerbangan bertanggung jawab dalam memberikan ganti rugi kepada pihak penumpang kecuali pihak maskapai penerbangan dapat membuktikan bahwa keterlambatan penerbangan tersebut disebabkan oleh faktor cuaca dan/atau teknis operasional. Dalam keterlambatan penerbangan yang disebabkan oleh kabut asap tidak dapat dikatakan sebagai force majeure karena dapat diprediksi oleh pihak maskapai penerbangan dan dapat dikatakan sebagai cuaca berkelanjutan. Atas dasar tersebut, maka pihak maskapai merupakan pihak yang bertanggungjawab dalam pemberian ganti rugi kepada penumpang. Hubungan antara pihak maskapai dengan penumpang juga terikat dengan perjanjian pengangkutan. Sehingga bentuk ganti rugi atas keterlambatan penerbangan harus sesuai dengan ketentuan yang terdapat dalam peraturan perundang-undangan sebagai bentuk tanggung jawab atas perjanjian pengangkutan yang tidak sesuai dengan kesepakatan.
\end{abstract}

Copyright () 2020 Universitas Airlangga

\section{Pendahuluan}

Seiring dengan perkembangan zaman, pengangkutan udara menjadi salah satu aspek penting dalam hubungan bisnis. Kondisi tersebut merupakan tuntutan kebutuhan masyarakat karena arus migrasi yang masif dan jangkauan wilayah 
yang dituju semakin luas serta didukung oleh kemajuan teknologi, telekomunikasi, dan transportasi. Terlebih Indonesia merupakan negara berbentuk kepulauan yang jarak tempuh antar pulau cukup jauh sehingga dengan pengangkutan udara masalah tentang jarak pun hanya menjadi sebuah masalah kecil. ${ }^{1}$ Jarak antar kota ataupun antar negara dapat dicapai dengan hanya hitungan jam. Semua masalah dapat dimudahkan dengan adanya jasa pengangkutan udara yang menjadi sangat penting di Indonesia. ${ }^{2}$

Pengangkutan udara juga dilaksanakan berdasarkan perjanjian pengangkutan. Perjanjian pengangkutan adalah suatu perjanjian dimana satu pihak menyanggupi untuk dengan aman membawa orang atau barang dari satu tempat ke tempat lain sedangkan pihak yang lain menyanggupi akan membayar ongkosnya. ${ }^{3}$ Perjanjian pengangkutan pada umumnya bersifat tidak tertulis (lisan) tetapi selalu didukung oleh dokumen pengangkut. Dokumen pengangkut sendiri memiliki fungsi sebagai bukti bahwa telah terjadi perjanjian pengangkutan dan wajib dilaksanakan oleh para pihak yang mengadakan perjanjian. Pada dasarnya dalam perjanjian pengangkutan terdapat dua pihak, yaitu pengangkut dalam hal ini adalah maskapai penerbangan dan pihak konsumen sebagai pengguna jasa pengangkutan. ${ }^{4}$

Dalam pelaku usaha jasa penerbangan yang telah mengadakan perjanjian dengan konsumen telah berjanji sesuai dengan yang tercantum dalam tiket penerbangan. Tiket tersebut bukan hanya sebagai bukti pembayaran saja, melainkan juga mengandung beberapa pasal dalam perjanjian yang secara tidak langsung telah dibuat antara pelaku usaha jasa penerbangan dengan konsumen. ${ }^{5}$

Perlindungan bagi konsumen berlaku untuk siapa saja yang bertindak sebagai konsumen, seperti yang telah dimaksud dalam Pasal 1 ayat (2) UUPK.

\footnotetext{
Abdulkadir Muhammad, Hukum Pengangkutan Niaga (Citra Aditya Bakti 2008).[7-8].

2 R. Soekardono, Hukum Dagang Indonesia Jilid II (Rajawali Press 1986).[4].

3 Subekti, Hukum Perjanjian (Internasional 1985).[1].

4 HM Purwosutjipto, Pengertian Pokok Hukum Dagang Indonesia : Hukum Pengangkutan (Djambatan 1995).[2].

5 Ashar Sinilele, 'Perlindungan Hukum Terhadap Penumpang Pada Transportasi Udara Niaga Pada Bandara Sultan Hasanuddin Makasar' (2016) 5 Jurnal Hukum.[199].
} 
Konsumen perlu dilindungi hak-haknya dikarenakan sering terjadi dalam kasus, konsumen merupakan pihak yang lemah sehingga perlu dilindungi haknya agar tidak terjadi kesewenang-wenangan dalam melakukan transaksi apapun dan juga konsumen merasa aman dan setara kedudukannya di mata hukum. Dengan ketentuan tersebut diharapkan konsumen memiliki benteng pengamanan sebagai pelindung dari tindakan sewenang-wenang pelaku usaha. ${ }^{6}$

Peraturan perundang-undangan telah mengatur sedemikian rupa mengenai keterlambatan penerbangan. Oleh karena itu, maskapai penerbangan mempunyai tanggung jawab untuk mengendalikan dan mengantisipasi terjadinya keterlambatan jadwal penerbangan. Dalam praktiknya, maskapai penerbangan belum maksimal melindungi konsumen selaku penumpangnya, sesuai peraturan perundang-undangan yang mengatur mengenai hak-hak konsumen/penumpang perusahaan penerbangan di Indonesia. Kondisi tersebut mengakibatkan penumpangnya sering dirugikan karena pelayanan yang diberikan, seperti keterlambatan jadwal penerbangan. ${ }^{7}$

Dalam permasalahan yang akan dibahas oleh penulis terkait kabut asap akibat kebakaran hutan dan lahan (karhutla) yang terjadi di Kalimantan, Sumatera dan Riau, menyebabkan syarat untuk laik terbang bagi maskapai penerbangan tidak terpenuhi. Beberapa maskapai penerbangan membatalkan puluhan penerbangan di sejumlah rute dosmetik. Maskapai penerbangan yang membatalkan penerbangan yakni, Lion Air, Wings Air, Nam Air, Batik Air, dan Garuda. Keputusan tersebut diambil karena cuaca buruk berupa kabut asap yang terjadi sehingga mengakibatkan jarak pandang pendek tidak memenuhi syarat keselamatan penerbangan, baik untuk proses lepas landas maupun pendaratan. Khususnya karena jarak pandang yang terbatas dianggap berisiko pada operasional penerbangan. Akibat kabut asap kebakaran jarak pandang menjadi lebih pendek, sehingga penundaan (delay) terpaksa dilakukan karena

\footnotetext{
2004).[1].

Ahmad Miru dan Sutarman Yodo, Hukum Perlindungan Konsumen (Raja Grafindo Persada

7 Annalisa Yahanan dan Kamal Halili, 'Tanggung Jawab Pengangkut Udara Terhadap Penumpang' (2010) 22 Jurnal Hukum.[236].
} 
ada gangguan jarak pandang sehingga hal tersebut masuk dalam kategori force majeure. Dari sisi konsumen sendiri merasa dirugikan dan tidak terpenuhi haknya dikarenakan penundaan penerbangan yang kurang jelas akibat kabut asap kebakaran. Kerugian yang dialami oleh penumpang tidak hanya kerugian materiil melainkan juga kerugian immateriil.

Berdasarkan latar belakang yang dikemukakakn di atas, maka rumusan permasalahan yang akan diteliti adalah sebagai berikut:

1. Pihak yang bertanggung jawab atas keterlambatan penerbangan;

2. Penegakan hukum atas keterlambatan penerbangan.

\section{Force Majeure Berdasarkan Peraturan Menteri Perhubungan Nomor 77 Tahun 2011 Jo. PM 92 Tahun 2011 tentang Tanggung Jawab Pengangkut Angkutan Udara}

Istilah force majeure berasal dari Bahasa Inggris. Pengertian force majeure menurut R. Setiawan yaitu suatu keadaan yang terjadi setelah dibuatnya perjanjian, yang menghalangi debitor untuk memenuhi prestasinya dimana debitor tidak dapat dipersalahkan dan tidak diwajibkan untuk menanggung risiko serta tidak dapat menduga pada waktu perjanjian dibuat. Hal tersebut terjadi sebelum debitor lalai untuk memenuhi prestasinya pada saat timbulnya keadaan force majeure. ${ }^{8}$

Peraturan Menteri Perhubungan Nomor 77 Tahun 2011 Jo. PM 92 Tahun 2011 tentang Tanggung Jawab Pengangkut Angkutan Udara (yang selanjutnya disebut sebagai PM 77 Tahun 2011 Jo. PM 92 Tahun 2011) memberikan perlindungan hukum kepada penumpang angkutan udara yang bergantung pada prinsip tanggung jawab pengangkut. Mengenai tanggung jawab pihak pengangkut atas keterlambatan penerbangan diatur dalam Pasal 9 PM 77 Tahun 2011 Jo. PM 92 Tahun 2011 yang menjelaskan terkait sistem tanggung jawab yang mengadopsi prinsip praduga untuk selalu bertanggung jawab (presumption of liability).

Sistem tanggung jawab yang digunakan dalam keterlambatan penerbangan (flight delayed) adalah prinsip praduga untuk selalu bertanggung jawab yang

\footnotetext{
8 R. Setiawan, Pokok-Pokok Hukum Perikatan : Cetakan Keenam (Putra A Bardin 1999).[27].
} 
dikombinasi dengan prinsip tanggung jawab dengan pembatasan. Dapat diartikan bahwa dalam hal ini pihak pengangkut selalu bertanggung jawab atas kerugian yang diderita penumpang pada setiap keterlambatan, akan tetapi pihak pengangkut dapat dibebaskan dari tanggung jawabnya apabila keterlambatan penerbangan tersebut disebabkan oleh faktor cuaca dan/atau faktor teknis operasional sebagaimana yang dimaksud dalam Pasal 13 ayat (1) PM 77 Tahun 2011 Jo. PM 92 Tahun 2011. Dalam pembuktian penyebab keterlambatan penerbangan ini adalah kewajiban pihak pengangkut itu sendiri.

Faktor cuaca sebagaimana yang diatur dalam Pasal 13 ayat (2) PM 77 Tahun 2011 Jo. PM 92 Tahun 2011 antara lain hujat lebat, petir, badai, kabut, asap, jarak pandang dibawah sandar minimal, atau kecepatan angin yang melampaui standar maksimal yang mengganggu keselamatan penerbangan. Faktor teknis operasional sebagaimana yang diatur dalam Pasal 13 ayat (3) PM 77 Tahun 2011 Jo. PM 92 Tahun 2011 yaitu ketika bandar udara untuk keberangkatan dan tujuan tidak dapat digunakan operasional pesawat udara, lingkungan menuju bandar udara atau landasan terganggu fungsinya seperti retak, banjir, atau kebakaran, terjadinya antrian pesawat udara lepas landas, mendarat, atau alokasi waktu keberangkatan di bandar udara, serta apabila terjadi keterlambatan pengisian bahan bakar.

Pihak pengangkut apabila dapat membuktikan bahwa keterlambatan penerbangan disebabkan oleh faktor cuaca atau yang bisa disebut sebagai force majeure, pihak pengangkut dapat dibebaskan dari tanggung jawabnya untuk memberikan ganti rugi kepada penumpang dengan alasan untuk menjaga keselamatan penumpang. Hal ini sesuai dengan Pasal 19 PM 77 Tahun 2011 Jo. PM 92 Tahun 2011 yang menjelaskan bahwa:

“Pengangkut tidak dapat dituntut tanggung jawab untuk membayar ganti rugi sebagaimana dimaksud dalam Pasal 3 huruf b, Pasal 3 huruf c butir 2, Pasal 14, apabila pengangkut dapat membuktikan bahwa:

a. Kejadian tersebut bukan karena kesalahan atau kelalaian pengangkut atau orang-orang yang dipekerjakannya atau agen-agennya; atau

b. Kejadian tersebut semata-mata disebabkan oleh kesalahan atau kelalaian penumpang sendiri dan/atau pihak ketiga." 


\section{Cuaca Secara Berkelanjutan Sebagai Alasan Force Majeure Keterlambatan Penerbangan}

Merujuk pada Pasal 5 ayat (4) PM 89 Tahun 2015 menyebutkan macammacam faktor cuaca sebagaimana dimaksud dalam Pasal 5 ayat (1) huruf c PM 89 Tahun 2015 meliputi:
a. Hujan lebat;
b. Banjir;
c. Petir;
d. Badai;
e. Kabut;
f. Asap;
g. Jarak pandang di bawah standar minimal; atau
h. Kecepatan angin yang melampaui standar maksimal yang mengganggu keselamatan penerbangan.

Matthew Schoonover mengatakan bahwa:

"The majority of delays are beyond the carrier's control. Weather alone accounts for almost half of all delays. Extreme weather delays result when conditions prevent all flight operations. Weather also can affect the entire National Aviation System, contributing to delays across the country. Although a city's weather is an important operating factor, selection of hub locations inly partially considers the delay risks at connection centers". ${ }^{9}$

Bahkan langit yang cerah pun tidak dapat menjamin penerbangan akan tepat waktu.

Dalam kasus kebakaran hutan dan lahan yang tejadi di Kalimantan, Sumatera, dan Riau menyebabkan kabut asap yang tebal sehingga berdampak pada aktivitas penerbangan. Pihak maskapai penerbangan menyatakan bahwa pesawat batal terbang dan mendarat dikarenakan kabut asap sehingga banyak penerbangan yang tertunda ataupun dibatalkan. Hal ini dilakukan demi keselamatan penumpang penerbangan.

Kegiatan penerbangan akan dilakukan setelah kabut asap menipis dan aman untuk penerbangan. Tebalnya kabut asap tersebut mempengaruhi jarak pandang dikarenakan pengaruhnya perubahan arah dan kecepatan angin. Terkait keterlambatan penerbangan, penanganan kepada penumpang penerbangan yang

\footnotetext{
9 Matthew Schoonover, 'Oversold, Delayed, Rescheduled: Airline Passenger Rights and Protections' (2011) 35 Washington University Journal of Law \& Policy.[527].
} 
terkena dampak kebakaran hutan dan lahan dilakukan sesuai dengan PM 89 Tahun 2015. Pihak otoritas bandara dan maskapai penerbangan menyatakan bahwa akan berusaha memberikan kemudahan bagi penumpang penerbangan sesuai dengan peraturan perundang-undangan yang berlaku juga memberikan kepedulian dan perhatian kepada calon penumpang penerbangan. ${ }^{10}$

Menurut Badan Pengkajian dan Penerapan Teknologi (BPPT), kabut asap yang disebabkan oleh kebakaran hutan dan lahan yang terjadi di Kalimantan, Sumatera, dan Riau merupakan cuaca berkelanjutan sehingga kabut asap tersebut bukan termasuk ke dalam keadaan force majeure dikarenakan hal tersebut telah diprediksisebelumnya sehingga pihakyang bersangkutan seharusnya bertanggung jawab secara penuh untuk mengganti kerugian akibat keterlambatan penerbangan sehingga tidak terlaksananya suatu kontrak dalam perjanjian pengangkutan.

Dapat dikatakan sebagai force majeure apabila memenuhi dua syarat sebagaimana tertuang dalam Pasal 1245 BW dan Pasal 1240 BW, yaitu pemenuhan harus tercegah dan pencegahan tersebut tidak dapat dipertanggungjawabkan oleh kreditor kepada debitor. Dalam hal ini, syarat pemenuhan harus tercegah dapat diartikan bahwa maskapai penerbangan sebagai debitor harus membuktikan bahwa ia telah berusaha untuk mencegah adanya kerugian dalam rangka memenuhi kewajibannya kepada konsumen sebagai kreditor. Syarat kedua dapat diartikan bahwa maskapai penerbangan harus mampu membuktikan bahwa kesalahan yang terjadi dalam pemenuhan kewajibannya yang telah dicegah dari terjadinya kerugian, bukanlah kesalahannya atau dapat dikatakan merupakan di luar kendalinya. Pemaknaan dari kedua syarat tersebut juga telah termaktub dalam Pasal 1444 BW. ${ }^{11}$

Maskapai penerbangan dalam permasalahan ini memang tidak mungkin memenuhi kewajiban pada waktunya, juga tidak langsung dapat dikatakan

10 Satrio Widianto, 'Kebakaran Hutan Dan Lahan Ganggu Banyak Penerbangan' (Pikiran Rakyat.com) <https://www.pikiran-rakyat.com/nasional/2019/09/17/kebakaran-hutan-dan-lahan-ganggu-banyak-penerbangan>. , accessed on 07-10-2019.

${ }_{11}$ Mr. J. H. Nieuwenhuis, Pokok-Pokok Hukum Perikatan : Terjemahan Djasadin Saraghi (Fakultas Hukum Universitas Airlangga 1985).[94-98]. 
bersalah dalam tercegahnya pemenuhan tersebut. ${ }^{12}$ Seyogyanya maskapai penerbangan mampu memperkirakan kabut asap yang menyebabkan terhambatnya penerbangan merupakan cuaca berkelanjutan yang menjadi risiko dalam pemenuhan kewajiban. Maskapai penerbangan sebagai pihak pengangkut meskipun tidak bersalah, ia harus bertanggung jawab atas kerugian yang terjadi. Dikatakan demikian karena sifat perjanjian penangkutan yang mewajibkan maskapai penerbangan memberikan jaminan, maka maskapai penerbangan juga harus bertanggung jawab atas kerugian tersebut. ${ }^{13}$ Pihak maskapai penerbangan memiliki kewajiban untuk memberikan kompensasi ganti rugi kepada penumpang karena cuaca yang berkelanjutan bukan termasuk dalam keadaan force majeure sesuai dengan Pasal 9 PM 89 Tahun 2015 mengenai pemberian kompensasi dan ganti rugi.

\section{Tanggung Jawab Pihak Maskapai Atas Keterlambatan Penerbangan}

Bentuk tanggung jawab pihak pengangkutan udara kepada penumpang termasuk dalam bentuk tanggung jawab berdasarkan unsur kesalahan (liability based on fault) yang didasarkan pada prinsip tanggung jawab mutlak (strict liability). Pasal 1365 BW sebagai landasan terbentuknya prinsip tanggung jawab mutlak yang menitikberatkan pada unsur kesalahan sehingga harus ada peraturan perundangundangan yang dilanggar. ${ }^{14}$ Pada realisasinya, tidak semua unsur kesalahan dapat dibuktikan bahkan sampai tidak dapat dibuktikan kemudian dikembangkan menjadi asas tanggung jawab mutlak (strict liability) untuk mengatasi keterbatasan kesalahan berdasarkan tanggung jawab tersebut. ${ }^{15}$

Prinsip tanggung jawab mutlak merupakan bentuk tanggung jawab perdata yang tidak memerlukan adanya unsur kesalahan sehingga beban pembuktian penggugat menjadi lebih ringan. Akan tetapi, penggugat tetap dibebani untuk

\footnotetext{
12 ibid.[99]. 2011).[31]

${ }^{13}$ Leonora Bakarbessy, Buku Ajar Hukum Perikatan (Fakultas Hukum Universitas Airlangga

${ }^{14}$ E. Suherman, Aneka Masalah Hukum Kedirgantaraan (Mandar Maju 2000).[36].

${ }^{15}$ K. Martono dan Amad Sudiro, Hukum Angkutan Udara Berdasarkan UU RI No. 1 Tahun 2009 : Cetakan II (Raja Grafindo Persada 2011).[217].
} 
membuktikan kerugian yang dialami sebagai akibat tindakan tergugat yang dapat dikatakan dengan pembuktian kausalitas. ${ }^{16}$ Pihak maskapai penerbangan sebagai pihak pengangkutan udara dianggap telah melanggar Pasal 9PM 77 Tahun 2011 Jo. PM 92 Tahun 2011 mengenai perjanjian pengangkutan udara dengan penumpang ketika terjadi:

1. Keterlambatan penerbangan (flight delayed);

2. Tidak terangkutnya penumpang dengan alasan kapasitas pesawat udara (derried boarding passanger);

3. Pembatalan penerbangan (cancelation of flight).

Bentuk tanggung jawab pihak pengangkut juga diatur dalam Pasal 2 PM 77 Tahun 2011 Jo. PM 92 Tahun 2011 yang menjelaskan bahwa pengangkut merupakan pihak yang mengoperasikan pesawat udara wajib bertanggung jawab atas segala kerugian terhadap:

a. Penumpang yang meninggal dunia, cacat tetap atau luka-luka;

b. Hilang atau rusaknya bagasi kabin;

c. Hilang, musnah, atau rusaknya bagasi tercatat;

d. Hilang, musnah, atau rusaknya kargo;

e. Keterlambatan angkutan udara; dan

f. Kerugian yang diderita oleh pihak ketiga.

Pasal 2 PM 77 Tahun 2011 Jo. PM 92 Tahun 2011 menjelaskan mengenai definisi keterlambatan penerbangan yang sering terjadi dan merugikan penumpang seperti tertundanya aktifitas-aktifitas penumpang yang seharusnya bisa dilakukan bahkan bisa kehilangan kesempatan-kesempatan yang akan datang. Dalam posisi yang kurang diuntungkan, pihak penumpang penerbangan dapat menggugat pihak maskapai penerbangan sesuai dengan Pasal 146 dan Pasal 147 UU Penerbangan. Menurut Pasal 146 dan Pasal 147 UU Penerbangan menjelaskan mengenai tanggung jawab pihak pengangkutan dan pemberian kompensasi kepada penumpang penerbangan. Bentuk tanggung jawab dapat berupa mengalihkan ke dalam penerbangan lain tanpa membayar biaya tambahan

\footnotetext{
16 Muhammad Pradika dan Adianto, 'Tanggung Jawab Maskapai Penerbangan Terhadap Keterlambatan Penerbangan' [2017] Mimbar Keadilan Jurnal Ilmu Hukum.[148].
} 
atau memberikan konsumsi serta akomodasi biaya untuk ke tempat tujuan.

Mengenai tanggung jawab pihak maskapai penerbangan terkait biaya pengembalian tiket (refund ticket), pihak maskapai penerbangan akan mengembalikan biaya yang sudah dikeluarkan oleh penumpang sesuai dengan bagaimana penumpang memberikan pembayaran sesuai dengan tiket yang dipilih kepada pihak maskapai penerbangan. Hal tersebut diatur dalam Pasal 10 ayat (1) dan (2) PM 89 Tahun 2015.

Pemberian kompensasi ganti rugi terkait keterlambatan penerbangan harus diberikan pihak maskapai penerbangan kepada penumpang sesuai yang sudah diatur dalam peraturan perundang-undangan yang berlaku. Dalam hal pemberian kompensasi ganti rugi, pihak maskapai penerbangan harus mencermati asas keseimbangan yang dimaksudkan untuk memberikan keseimbangan antara kepentingan penumpang dan pihak maskapai penerbangan sendiri yang bertindak sebagai pelaku usaha sesuai yang telah diatur dalam Pasal 2 UUPK. ${ }^{17}$

Berdasarkan ketentuan-ketentuan hukum perjanjianyang mendasarkan pada wanprestasi memiliki ruang lingkup yang sempit, karena dibatasi oleh "privity of contract" sehingga pelaku usaha hanya bertanggung jawab terhadap pihakpihak dalam hubungan kontraktual (perjanjian). ${ }^{18}$ Diharapkan pihak maskapai penerbangan dapat mengakomodir segala macam kepentingan-kepentingan baik antara pihak penumpang dengan pihak maskapai penerbangan sebagai pelaku usaha secara seimbang, baik dari aspek regulasi maupun penegakkan normanorma perlindungan konsumen.

\section{Kepastian Hukum Force Majeure Sebagai Alasan Keterlambatan Penerbangan Dalam Instrumen Hukum di Indonesia}

Hubungan hukumantara para pihak dalam perjanjian pengangkutan terdapat dua pihak, yaitu pihak pengangkut dalam hal ini pihak maskapai penerbangan

\footnotetext{
17 Abdulkadir Muhammad (n 1).,Op.Cit.[43].

18 Bambang Sugeng Ariadi S Sri Handajani, Gianto Al Imron, Buku Ajar Hukum Perlindungan Konsumen (Fakultas Hukum Universitas Airlangga 2006).[109].
} 
atau perusahaan dan pihak pengguna jasa atau konsumen. ${ }^{19}$ Para pihak yang saling terikat merupakan pihak konsumen yang menyatakan kesanggupannya untuk memberikan biaya transportasi sedangkan pihak maskapai penerbangan menyatakan kesanggupannya untuk memberikan jasa penerbangan setelah biaya transportasi tersebut dibayarkan. Hak dan kewajiban itulah yang dikenal dengan bentuk prestasi sesuai dengan Pasal 1234 BW yang menjelaskan tentang tiap-tiap perikatan adalah untuk memberikan sesuatu, untuk berbuat sesuatu, atau untuk tidak berbuat sesuatu.

Aspek yuridis dalam pelaksanaan perjanjian pengangkutan udara adalah tanggung jawab atas kerugian-kerugian yang diluar perhitungan sehingga sering terjadi penyimpangan dalam pelaksanaannya. Adanya hubungan yang saling bergantung antara pihak pengangkut dengan konsumen selaku pengguna jasa seharusnya mampu menempatkan kesetaraan kedudukan antara pihak pengangkut dengan pihak konsumen sehingga dapat memberikan perlindungan hukum yang total kepada para pihak. ${ }^{20}$

Dalam perjanjian pengangkutan, perlindungan hukum ditujukan kepada pihak konsumen sebagai pengguna jasa yang berarti segala upaya untuk menjamin adanya kepastian hukum dalam memberikan perlindungan konsumen yang sesuai dengan Pasal 1 ayat (1) UUPK. ${ }^{21}$ Perlindungan hukum bagi pengguna jasa pengangkutan udarajuga diatur dalam UU Penerbangan dimana pihak pengangkut bertanggung jawab atas pengguna jasa angkutan udara yang mengalami kerugian. Dalam pelaksanaan kegiatan angkutan udara tersebut terdapat payung hukum sebagai penjamin adanya kepastian tentang kedudukan serta hak dan kewajiban masing-masing pihak dalam terselenggaranya perjanjian pengangkutan sehingga prestasi tersebut dapat dipenuhi dan kerugian dapat dihindari.

Pembatalan penerbangan pada umumnya disebabkan oleh dua faktor yaitu internal management maskapai udara yang bersifat teknis dan dapat

\footnotetext{
${ }^{19}$ HM Purwosutjipto (n 4).,Op.Cit.[3]

20 ibid.[7].

${ }^{21}$ ibid.[8].
} 
terus diperbaiki oleh pihak yang bersangkutan dan dievaluasi untuk menjaga kepercayaan dari para konsumennya sedangkan faktor eskternal dapat disebabkan adanya force majeure berbentuk bencana alam atau kabut asap yang dapat menganggu penerbangan.

Pada dasarnya, kepastian hukum terkait force majeure sebagai alasan keterlambatan penerbangan hanya diatur dalam UU Penerbangan dan PM77Tahun 2011 Jo. PM 92 Tahun 2011, sedangkan dalam peraturan perundang-undangan tersebut dapat merugikan pihak konsumen sebagai pengguna jasa pengangkutan udara dan lebih menguntungkan pihak maskapai penerbangan dengan menggunakan alasan force majeure agar dapat dibebaskan untuk melaksanakan prestasinya. ${ }^{22}$ Terkait perlindungan hukum kepada pihak konsumen sebagai pengguna jasa pengangkutan udara hanya diatur dalam Pasal 4 huruf h UUPK yang menyatakan bahwa hak konsumen untuk mendapatkan kompensasi, ganti rugi dan/atau penggantian, apabila barang dan/atau jasa yang diterima tidak sesuai dengan perjanjian atau tidak sebagaimana mestinya.

Tidak diatur secara jelasnya mengenai force majeure terkait cuaca berkelanjutan dalam UUPK, pihak maskapai penerbangan sebagai penyedia jasa angkutan udara melakukan perjanjian pengangkutan udara dengan penumpang, dimana perjanjian pengangkutan udara merupakan suatu perjanjian antara pihak maskapai penerbangan dengan pihak penumpang yang bersifat timbal balik. Dapat dikatakan timbal balik karena pihak maskapai penerbangan dan pihak penumpang sebagai subjek dalam perjanjian pengangkutan udara, satu sama lain saling berjanji, dimana masing-masing pihak memiliki hak dan kewajiban. ${ }^{23}$ Penumpang sebagai pengguna jasa pengangkutan udara berhak untuk mendapatkan kompensasi ganti rugi akibat faktor force majeure sebagai alasan keterlambatan penerbangan karena dalam hal ini penumpang merasa dirugikan secara materiil dan immateriil.

\footnotetext{
${ }^{22}$ Annalisa Yahanan dan Kamal Halili (n 7).,Op.Cit.[238].

${ }^{23}$ Diva Danica dan I Made Dedy Priyanto, 'Tanggung Jawab Maskapai Penerbangan Terhadap Keterlambatan Transit Dalam Penerbangan Lanjutan' (2015) 3 Jurnal Ilmu Hukum.[11].
} 


\section{Perlindungan Hukum Terhadap Konsumen Atas Keterlambatan Penerbangan}

Perlindungan hukum terhadap konsumen yang menggunakan jasa angkutan udara telah dilindungi dengan UU Penerbangan yang diderivatif dalam PM 77 Tahun 2011 Jo. PM 92 Tahun 2011 dan UUPK. Terhadap kerugian yang diderita konsumen akibat dari keterlambatan angkutan udara sesuai dengan Pasal 23 PM 77 Tahun 2011 Jo. PM 92 Tahun 2011 dimana pihak konsumen dapat mengajukan tuntutan ganti rugi kepada pihak pengangkut penerbangan. Dalam Pasal 21 PM 77 Tahun 2011 Jo. PM 92 Tahun 2011 diatur suatu ketentuan mengenai persyaratan dan tata cara pengajuan tuntutan ganti kerugian, dalam Pasal 21 ayat (1) PM 77 Tahun 2011 Jo. PM 92 Tahun 2011 diatur bahwa tuntutan ganti kerugian atas keterlambatan hanya dapat dilakukan berdasarkan bukti, yaitu dalam hal ini berupa tiket pesawat. Tiket pesawat tersebut dapat menjadi bukti bahwa konsumen adalah memang benar sebagai penumpang pesawat dari pengangkut, serta bukti tiket pesawat akan menjelaskan berapa jeda waktu antara keberangkatan pesawat yang tertulis di tiket dengan keberangkatan faktualnya. ${ }^{24}$

Dalam UUPK mengakomodir mengenai salah satu hak konsumen, yaitu hak atas memperoleh informasi yang benar, jelas, dan jujur. Hal ini tertera dalam Pasal 4 UUPK. Informasi yang benar, jelas, dan jujur tentu meliputi informasi keterlambatan pada maskapai penerbangan karena hal tersebut sangat penting bagi pihak penumpang penerbangan ${ }^{25}$ apabila konsumen tidak menerima hal tersebut, maka konsumen yang bersangkutan dapat menuntut kepada pihak pengangkutan udara untuk memenuhi haknya dan maskapai penerbangan, dalam hal ini sebagai pihak pengangkutan udara dianggap telah merugikan konsumen.

Telah dirugikannya konsumen, maka maskapai penerbangan bertanggung jawab dalam memberikan ganti rugi atas kerugian dari jasa yang dihasilkan. Ganti rugi tersebut dapat berupa pengembalian uang atau penggantian barang dan/atau jasa yang sejenis atau setara nilainya, atau perawatan kesehatan dan/

${ }^{24}$ Nurlely Darwis, 'Aspek Hukum Pengguna Jasa Transportasi Udara Komersil' (2017) 7 Jurnal Ilmu Hukum Dirgantara.[2].

${ }^{25}$ Muhammad Pradika dan Adianto (n 16).,Op.Cit.[153]. 
atau pemberian santunan yang sesuai dengan ketentuan peraturan perundangundangan yang berlaku. Ganti rugi dapat dilaksanakan dalam jangka waktu 7 (tujuh) hari setelah tanggal transaksi dalam perjanjian pengangkutan. Pemberian ganti rugi ini tidak menghapuskan kemungkinan adanya tuntutan pidana berdasarkan pembuktian lebih lanjut mengenai adanya unsur kesalahan. Terdapat pengecualian untuk pemberian ganti rugi ini, bahwa ganti rugi ini tidak berlaku apabila maskapai penerbangan dapat membuktikan bahwa kesalahan yang terjadi merupakan kesalahan konsumen. Ketentuan mengenai pemberian ganti rugi oleh maskapai penerbangan telah diatur di dalam Pasal 19 UUPK.

Jika konsumen tidak mendapatkan pelayanan yang layak terhadap pengguna jasa angkutan udara, dapat mengajukan laporan keluhan mengenai maskapai penerbangan kepada perusahaan penerbangan seperti melalui call center maskapai penerbangan sesuai dengan yang tertera dalam tiket pesawat. Laporan keluhan mengenai pelayanan maskapai merupakan suatu bentuk perlindungan hukum yang diberikan oleh undang-undang. ${ }^{26}$

Tidak dipenuhinya kewajiban pemberian ganti rugi terhadap konsumen yang dirugikan oleh maskapai penerbangan, menimbulkan adanya konsekuensi bahwa salah satu pihak dapat menyelesaikan permasalahan ini dengan penyelesaian sengketa secara hukum berdasarkan ketentuan UUPK. Merujuk Pasal 45 UUPK yang menyatakan bahwa setiap konsumen yang merasa dirugikan dapat menggugat pihak pengangkutan sebagai pelaku usaha melalui lembaga yang bertugas menyelesaikan sengketa antara konsumen dan pelaku usaha yang merasa haknya dilanggar oleh pihak pengangkutan, maka Negara memberikan suatu bentuk wadah perlindungan hukum bagi konsumen. ${ }^{27}$

Merujuk pada Pasal 46 UUPK maka cara penyelesaian sengketa konsumen berdasarkan UUPK dapat menggunakan 2 mekanisme, yaitu:

${ }^{26}$ Nadhia Amania Sadidha, ‘Pemberian Ganti Rugi Delay PT. Lion Mentari Airlines Ditinjau Dari UU No. 1 Tahun 2009 Tentang Penerbangan' [2016] Program Sarjana Universitas Airlangga. [70].

27 Shidarta, Hukum Perlindungan Konsumen Indonesia (Gramedia Widiasarana Indonesia 2000). 
1. Tuntutan Seorang Konsumen

Tuntutan yang dilakukan oleh orang perseorangan yang jumlahnya hanya 1 orang. Dapat diajukan kepada Badan Penyelesaian Sengketa Konsumen (yang selanjutnya disebut sebagai BPSK). Gugatan yang diajukan oleh konsumen melalui BPSK hanya dapat dilakukan atas dasar kesepakatan para pihak. Mekanisme gugatan dilakukan secara sukarela dari kedua belah pihak yang bersengketa. BPSK memfasilitasi penanganan dan penyelesaian sengketa konsumen dengan cara konsiliasi, mediasi, atau arbitrase sesuai dengan Pasal 52 huruf a UUPK. Ketiga cara tersebut, masing-masing berdiri sendiri dan para pihak yang bersengketa dapat memilih cara mana yang dipilih untuk menyelesaiakan sengketa konsumen ini.

a. Konsiliasi;

b. Mediasi;

c. Arbitrase.

2. Gugatan Kelompok (Class Action)

Pihak-pihak yang dapat mengajukan class action hanyalah sekelompok orang yang mempunyai kepentingan serta fakta yang sama sesuai dengan penjelasan Pasal 46 ayat (1) UUPK yang dapat dibuktikan secara hukum, salah satu diantaranya adalah adanya bukti transaksi, ${ }^{28}$ dengan memperhatikan beberapa prinsip dalam rangka pengajuan dan pemeriksaannya. Mekanisme pemeriksaan gugatan kelompok harus disesuaikan dengan ketentuan yang terdapat dalam Peraturan Mahkamah Agung No. 1 Tahun 2002 tentang Acara Gugatan Perwakilan Kelompok. ${ }^{29}$ Gugatan yang diajukan oleh sekelompok konsumen (class action), dapat diajukan ke peradilan umum sesuai dengan Pasal 46 ayat (2) UUPK.

Dalam kasus ini, apabila kedua belah pihak yaitu pihak penumpang pengangkutan udara dan pihak maskapai penerbangan tidak menemukan titik

${ }^{28}$ Bambang Sugeng Aariadi Subagyono, 'Penyelesaian Sengketa Konsumen Melalui Gugatan Kelompok' (2010) 25 Yuridika.[120].

29 ibid. 
penyelesaian yang seimbang, maka pihak penumpang pengangkutan udara dapat mengajukan gugatan tersebut ke BPSK. Pihak pengangkutan udara bertanggung gugat ketika pihak penumpang mengajukan gugatan kepada pihak pengangkutan udara apabila mengalami kerugian yang disebabkan oleh pihak pengangkutan itu sendiri sehingga pihak penggangkut wajib memberikan ganti rugi kepada pihak penumpang sebagai pihak yang dirugikan. Penyelesaian sengketa konsumen di luar pengadilan merupakan salah satu jalur alternatif dalam penyelesaian sengketa konsumen yang diharapkan mampu memberikan perlindungan hukum kepada konsumen yang lebih efektif dan efisien. Selain itu, penyelesaian sengketa konsumen di luar pengadilan diharapkan dapat membantu menyelesaikan sengketa kosumen dengan lebih cepat, mudah, dan biaya yang lebih murah. Putusan BPSK bersifat final dan mengikat yang dapat menjamin kepastian hukum dalam menyelesaikan sengketa dalam perlindungan konsumen.

\section{Kesimpulan}

Maskapai penerbangan sebagai pihak pengangkut mempunyai tanggung jawab dalam memberikan ganti kerugian karena keterlambatan penumpang pada angkutan udara kecuali pengangkut dapat membuktikan bahwa keterlambatan penerbangan tersebut disebabkan faktor cuaca dan/atau teknis operasional sedangkan keterlambatan atau pembatalan penerbangan yang dikarenakan kabut asap tidak dapat dikatakan sebagai force majeure karena maskapai tidak mampu memenuhi syarat dikatakannya force majeure. Kabut asap seharusnya telah dapat diperkirakan oleh pihak maskapai dan dapat dikatakan sebagai cuaca berkelanjutan. Bentuk kompensasi atas keterlambatan penerbangan tersebut dapat berupa pengembalian uang baik sebagian maupun sepenuhnya, pengalihan penerbangan dengan biaya yang dijamin sampai dengan memberikan konsumsi, akomodasi, dan biaya transportasi apabila tidak ada penerbangan ke tujuan yang diperjanjikan. Dalam hal pemberian kompensasi ganti rugi, pihak maskapai penerbangan harus memperhatikan asas keseimbangan guna memberikan keseimbangan antara kepentingan penumpang dan pihak maskapai penerbangan sebagai pelaku usaha. 
Upaya hukum yang dilakukan jika konsumen dirugikan akibat keterlambatan penerbangan adalah mengajukan ganti kerugian atau klaim kepada perusahaan penerbangan melalui call center sesuai dengan maskapai penerbangan yang tertera dalam tiket pesawat masing-masing konsumen. Tidak dipenuhinya kewajiban dalam pemberian ganti rugi kepada konsumen oleh pihak maskapai penerbangan yang tidak sesuai dengan peraturan yang ada maka konsumen dapat menyelesaikan sengketa yang dapat ditempuh melalui dua jalur yaitu jalur litigasi dan jalur non litigasi melalui BPSK. Kedua model penyelesaian sengketa tersebut diakui di dalam Undang-Undang Nomor 8 Tahun 1999 Tentang Perlindungan Konsumen.

\section{Daftar Bacaan}

\section{Buku}

Abdulkadir Muhammad, Hukum Pengangkutan Niaga (Citra Aditya Bakti 2008).

Ahmad Miru dan Sutarman Yodo, Hukum Perlindungan Konsumen (Raja Grafindo Persada 2004).

E. Suherman, Aneka Masalah Hukum Kedirgantaraan (Mandar Maju 2000).

HM Purwosutjipto, Pengertian Pokok Hukum Dagang Indonesia : Hukum Pengangkutan (Djambatan 1995).

K. Martono dan Amad Sudiro, Hukum Angkutan Udara Berdasarkan UU RI No. 1 Tahun 2009 : Cetakan II (Raja Grafindo Persada 2011).

Leonora Bakarbessy,[et.,al.], Buku Ajar Hukum Perikatan (Fakultas Hukum Universitas Airlangga 2011).

Mr. J. H. Nieuwenhuis, Pokok-Pokok Hukum Perikatan : terjemahan Djasadin Saraghi (Fakultas Hukum Universitas Airlangga 1985)

R. Setiawan, Pokok-Pokok Hukum Perikatan : Cetakan Keenam (Putra A Bardin 1999).

R. Soekardono, Hukum Dagang Indonesia Jilid II (Rajawali Press 1986).

Shidarta, Hukum Perlindungan Konsumen Indonesia (Gramedia Widiasarana Indonesia 2000).

Sri Handajani, Gianto Al Imron, Bambang Sugeng Ariadi S., Buku Ajar Hukum 
Vermonita Dwi: Perlindungan Hukum bagi...

Perlindungan Konsumen (Fakultas Hukum Universitas Airlangga 2006).

Subekti, Hukum Perjanjian (Internasional 1985).

\section{Jurnal}

Annalisa Yahanan dan Kamal Halili, 'Tanggung Jawab Pengangkut Udara Terhadap Penumpang', (2010), 22 Jurnal Hukum.

Bambang Sugeng Ariadi Subagyono, 'Penyelesaian Sengketa Konsumen Melalui Gugatan Kelompok', (2010), 25 Yuridika.

Diva Danica dan I Made Dedy Priyanto, 'Tanggung Jawab Maskapai Penerbangan Terhadap Keterlambatan Transit Dalam Penerbangan Lanjutan', (2015), 3 Jurnal Ilmu Hukum.

Matthew Schoonover, 'Oversold, Delayed, Rescheduled: Airline Passenger Rights and Protections', (2011), 35 Washington University Journal of Law \& Policy.

Muhammad Pradika dan Adianto, 'Tanggung Jawab Maskapai Penerbangan Terhadap Keterlambatan Penerbangan', (2017), Mimbar Keadilan Jurnal Ilmu Hukum.

Nurlely Darwis, 'Aspek Hukum Pengguna Jasa Transportasi Udara Komersil', (2017), 7 Jurnal Ilmu Hukum Dirgantara.

Shinta Nuraini, Tanggung Jawab Keperdataan Dalam Penyelenggaraan Pengangkutan Udara Atas Keterlambatan Jadwal Penerbangan Berdasarkan Undang-Undang Nomor 1 Tahun 2009 tentang Penerbangan, (2017), 5 Jurnal Privat Law.

\section{Skripsi}

Nadhia Amania Sadidha, ‘Pemberian Ganti Rugi Delay PT. Lion Mentari Airlines Ditinjau Dari UU No. 1 Tahun 2009 Tentang Penerbangan', (2016), Skripsi, Program Sarjana Universitas Airlangga.

\section{Laman}

Satrio Widianto, 'Kebakaran Hutan dan Lahan Ganggu Banyak Penerbangan', https://www.pikiran-rakyat.com/nasional/2019/09/17/kebakaran-hutandan-lahan-ganggu-banyak-penerbangan, accessed on 7 Oktober 2019.

How to cite: Vermonita Dwi Caturjayanti, 'Perlindungan Hukum bagi Konsumen terhadap Keterlambatan Penerbangan Akibat Kabut Asap Kebakaran' (2020) Vol. 3 No. 2 Media Iuris. 